Tér és Társadalom 24. évf. 2010/1. 137-154. p.

Tér és Társadalom

XXIV. évf. 2010 1: 137-184

KITEKINTÖ

\title{
A LÉGI KÖZLEKEDÉSI SZEKTOR LIBERALIZÁCIÓJA ÉS AZ EURÓPAI FAPADOS PIAC
}

\author{
(The Liberalization of the Aviation Industry and the European \\ Low-cost Market)
}

\section{DUDÁS GÁBOR}

Kulcsszavak:

fapados légitársaságok liberalizáció low-costmodell útvonalhálózat

Az európai légtér liberalizációja felszabadította a korábban igen szabályozott légi közlekedési piacot, és új müködési keretet hozott létre az Európai Közösség területén üzemelö légitársaságoknak. Az új helyzetet kihasználva üj piaci szereplók is megjelentek Európa égboltján a diszkont légitársaságok formájában, melyek gyorsan számottevó piaci részesedésre tettek szert és komoly versenytársaivá váltak a hagyományos légitársaságoknak.

Kezdetekben a fapados forgalom teljes mértékben a nyugat-európai térségre koncentrálódott, itt alakította ki egyedi útvonalhálózatát és üzleti struktúráját. Az Európai Unio keleti bóvítésének hatására a diszkont légitársaságok megjelentek Kelet-Európában is, ahol szembesülve az ájfajta piaci kereslettel, itt is hamar komoly piaci részt hóditottak el a nemzeti légitársaságoktól. E tanulmánynak az a célja, hogy bemutassa az európai fapados piac alakulását, különös hangsúlyt fektetve az Európai Unió keleti bóvítésének hatásaira. Vizsgálataink alapján arra a következtetésre jutottunk, hogy az uniós bỏvítés óta eltelt idóben bövült az európai fapados útvonalhálózat, és a keleti piacok újfajta kereslettel találták szembe magukat, amely három csoportból, az üzleti utazók egy új rétegéböl, a városlátogató turistákból, valamint a külföldön élö munkások posztmigrációs áramlásaiból kerül ki.

\section{Bevezetés}

Korunkban a légi közlekedés a világ egyik legdinamikusabban fejlödỏ szektora. Ezt a sikerét a globalizálódó világban lejátszódó folyamatoknak köszönheti, hiszen egyre nagyobb érték az idő, és a nagy távolságok leggyorsabb megtételének eszköze a repülögép. A légi közlekedés lehetővé teszi emberek millióinak távoli helyekre valo utazását és a nagy értékủ termékek rövid időn belüli piacra juttatását, elösegíti az egyes térségeknek a meghatározó piacokhoz való csatlakozását és a termelés globalizációját, emellett a turizmusban játszott pozitív szerepével segíti a gazdasági növekedést, és munkahelyeket is teremt (Selymes 2009).

Európában a piaci szabályozás megszüntetése jelentette a légi közlekedési szektor gyors növekedésének alapját, és itt is, mint szerte a világon a fapados légitársaságok 
lettek a piaci liberalizáció nyertesei. Kihasználva a hagyományos légitársaságok által elhanyagolt piaci részt, újfajta üzletstratégiájukkal (alacsony repülőjegy árak, kiadások csökkentése stb.) gyorsan komoly versenytársaivá váltak a hagyományos légitársaságoknak. Az Európai Unió 2004-es bővítése a keleti piacoknak is új dinamikát adott, és a fapados légitársaságok gépei megjelentek Kelet-Európa égboltján is.

E tanulmány célja annak a vizsgálata, hogy az Európai Unió bővítésével az európai fapados piacon milyen változások következtek be, valamint a kelet-európai piac liberalizációja után hogyan módosultak az egyes légitársaságok útvonalhálózatai, és az újonnan alakult keleti fapados légitársaságok milyen piaci részesedésre tettek szert. Emellett fontosnak tartottuk megvizsgálni, hogy az új keleti piacok milyen keresletet indukálnak, valamint, hogy a kelet-európai utasok utazási motivációi különböznek-e a nyugat-európaiakétól.

Tanulmányunk első felében röviden összefoglaljuk az európai légi közlekedési piac liberalizációs folyamatait, valamint az ennek köszönhetően megjelenő és egyre nagyobb mértékben elterjedő fapados légitársaságok általános jellemzőit, illetve speciális üzletpolitikájuk alapjait. Ezt követően külföldi szakirodalom felhasználásával, illetve egyéni adatgyűjtés segítségével felvázoljuk, hogy az Európai Unió keleti bővítése óta eltelt időszakban milyen változások történtek az európai fapados piacon, elsősorban a kelet-európai piacra fókuszálva.

\section{Alkalmazott módszerek}

A kutatás során az egyik fỏ nehézséget az elemzési egységek, azaz a diszkont légitársaságok azonosítása jelentette, hiszen nincs róluk naprakész lista, és nem minden low-cost légitársaság tagja az ELFAA ${ }^{1}$-nak. Ugyanakkor bizonyos légitársaságok „fapadosoknak" állítják be magukat, annak ellenére, hogy a hagyományos légitársaságok árain szolgáltatnak, köszönhetỏen a sok és változatos extradíjnak. Ezen felül a fapadosok helyzete is gyorsan változik, amelyben komoly szerepet játszanak a csődök (Sterling Airways), egyesülések (pl. a Clickair és a Vueling fúziója) és új légitársaságok alakulása.

A dinamikus változások miatt nem hagyatkozhattunk a korábban publikált fapados listákra, hanem összeállítottuk az aktuális (2009. július) helyzetet tükrözö besorolást. Ennek készítése során először a korábbi irodalmak (CAA 2006; Dobruszkes 2006; 2009a; Graham-Shaw 2008) alapján, valamint az interneten megtalálható adatbázisokból létrehoztunk egy bő listát, amelyben a magukat fapadosnak nyilvánító légitársaságok szerepeltek. Ezután meghatározott útvonalakon összehasonlítottuk a diszkont- és a hagyományos légitársaságok árait ${ }^{2}$. Az összevetésre szolgáló árakat 2009. július 16-án kérdeztük le egy, valamint három hónappal előre. Azokat a légitársaságokat tekintettük low-cost társaságoknak, amelyek árai az adott útvonalakon nem haladták meg a hagyományos légitársaságok árainak 66\%-át (Dobruszkes 2006). Ennek alapján 2009 júliusában 18 légitársaságot nevezhettünk ténylegesen is fapados társaságnak (1. táblázat). 
Dudás Gábor : A légi közlekedési szektor liberalizációja és az európai fapados piac.

Tér és Társadalom 24. évf. 2010/1. 137-154. p.

TÉT XXIV. évf. 2010 " 1

Kitekintö

139

\section{TÁBLÁZAT}

Az európai fapados légitársaságok útvonalhálózatának adatai, 2009

(European LCCs Network Data, 2009)

\begin{tabular}{lccccccc}
\hline $\begin{array}{c}\text { Légi- } \\
\text { társaságok }\end{array}$ & $\begin{array}{c}\text { Or- } \\
\text { szág }\end{array}$ & $\begin{array}{c}\text { Célállo- } \\
\text { mások } \\
\text { száma }\end{array}$ & $\begin{array}{c}\text { Útvona- } \\
\text { lak } \\
\text { száma }\end{array}$ & $\begin{array}{c}\text { Orszá- } \\
\text { gok } \\
\text { száma }\end{array}$ & $\begin{array}{c}\text { Repülö- } \\
\text { gépek } \\
\text { száma }\end{array}$ & $\begin{array}{c}\text { Mükö- } \\
\text { dés } \\
\text { kezdete }\end{array}$ & $\begin{array}{c}\text { Magyaror- } \\
\text { szágról elér- } \\
\text { hetö célállo- } \\
\text { mások }\end{array}$ \\
\hline Aer Lingus* & IRE & 59 & 88 & 20 & 33 & 1936 & 1 \\
Blue Air & ROM & 34 & 45 & 11 & 8 & 2004 & - \\
bmibaby & UK & 29 & 63 & 8 & 20 & 2002 & - \\
easyJet & UK & 110 & 445 & 27 & 167 & 1995 & 6 \\
Flybe & UK & 56 & 162 & 12 & 59 & 2002 & - \\
Flyglobespan* & UK & 20 & 36 & 9 & 9 & 2002 & - \\
Germanwings & GER & 66 & 121 & 25 & 27 & 2002 & 2 \\
Jet2 & UK & 48 & 105 & 19 & 31 & 2002 & 1 \\
Monarch & UK & 19 & 49 & 4 & 31 & 1967 & - \\
Myair & ITA & 31 & 50 & 13 & 9 & 2004 & - \\
Norwegian & NOR & 75 & 164 & 24 & 45 & 1993 & 4 \\
Ryanair & IRE & 145 & 818 & 25 & 183 & 1985 & 4 \\
SkyEurope & SVK & 33 & 57 & 17 & 14 & 2002 & - \\
Transavia & NED & 68 & 96 & 16 & 29 & 1966 & - \\
TUIfly & GER & 70 & 272 & 14 & 44 & 2007 & - \\
Vueling & ESP & 44 & 89 & 17 & 35 & 2004 & 1 \\
Windjet & ITA & 29 & 46 & 13 & 12 & 2003 & - \\
Wizzair & HUN & 52 & 143 & 19 & 26 & 2003 & 19 \\
\hline
\end{tabular}

* A légitársaságok észak-amerikai célállomásait a táblázat nem tartalmazza.

Forrás: A légitársaságok honlapjai alapján szerkesztette a szerző.

A diszkont légitársaságok útvonalhálózatának meghatározásához és megrajzolásához létrehoztunk egy adatbázist, amelyben a 18 európai fapados légitársaság által elérhető városok és a közöttük lévő kapcsolatok szerepeltek. A begyűjtött adatokat, - amelyek a 2009. júliusi állapotokat tükrözik - felhasználva tematikus térképeket szerkesztettünk, amelyek az Európai Unió keleti bővítése előtti állapottal való öszszehasonlítás alapjául szolgáltak.

A későbbiekben - a korábbi kutatásokkal való összehasonlíthatóságot szolgáló azonos fogalomhasználat miatt - Nyugat-Európa alatt az EU15-ök országait, valamint Izlandot, Norvégiát és Svájcot, míg Kelet-Európa országai alatt az Unióhoz frissen csatlakozott további 12 államot értjük. 
Dudás Gábor : A légi közlekedési szektor liberalizációja és az európai fapados piac.

Tér és Társadalom 24. évf. 2010/1. 137-154. p.

140 Kitekintó

TÉT XXIV. évf. 2010

\section{Az európai légi közlekedési piac liberalizációja}

Mielőtt a légi közlekedés jelenlegi térfolyamatait elemeznénk, érdemes áttekintenünk a szektorban végbement deregulációs folyamatokat, elsösorban az európai térségre koncentrálva.

A II. világháború után a polgári légi közlekedés dinamikusan fejlödött, de a növekvő nemzetközi forgalom szabályozásához egységes internacionális egyuittmủködésre volt szükség. Az 1944-ben 52 állam részvételével rendezett chicagói konferencián 3 fó célkitüzést fogalmaztak meg, miszerint a nemzetközi légi közlekedést szabályozni kell, ki kell dolgozni a nemzetközi légi közlekedési jogokat, valamint meg kell teremteni a légi közlekedés nemzetközi intézményrendszerét (Erdösi 1997; 1998; Doganis 2006). A konferencián elfogadták a Chicagói Egyezményt, amely a modern légi közlekedés egyik alapdokumentuma lett, és megteremtette a ma is használatos jogi és rendezéselvi keretek alapjait. Az egyezményben rögzítették, hogy minden állam maga rendelkezik a területe feletti légtérrel, és megfogalmazták a légtér használatának több szabadságjogát, azonban a ma is érvényben lévő nyolc szabadságjog csak a későbbiekben alakult ki a piaci kötöttségek folyamatos oldódásával.

A Chicagói Egyezmény következményeként a nemzetközi légi forgalmat több ezer bilaterális szerződés szabályozta (Button 2009), melyeket az egyes országok kormányai kötöttek egymással. Ezeknek a fö alapelve a kölcsönösség és egyenlőség volt (Goetz-Graham 2004), beleértve ebbe az együttesen meghatározott tarifákat, a járatok kapacitását, valamint a járatok és útvonalak számát.

Egy ilyen szabályozott ágazatban a nagy nemzeti légitársaságok uralták a piacot, és igazi versenyhelyzet hiányában nem volt indokolt számukra, hogy új piaci szegmensek vagy saját útvonalhálózatuk hibái után kutassanak. Az amerikai légi közlekedési piac liberalizációja azonban alapvetô változásokat eredményezett a légitársaságok útvonalainak hálózatszerkezetében és üzleti politikájában, hiszen az árakat jobban a kiadásokhoz kellett igazítani, a müködésnek hatékonnyá és profitot termelővé kellett válnia. A dereguláció következményeként a hagyományos légitársaságok a ponttól-pontig való szállításról áttértek a hub-and-spoke rendszerre (amelyben kevesebb a közvetlen kapcsolat az egyes célállomások között, mivel egy-egy központi repülőtér osztja el a hálózat forgalmát), hiszen a piaci korlátok megszúnésével az árakat elsősorban a kereslet diktálta, és felértékelődött a méretgazdaságosság szerepe. Ezzel szemben a diszkont légitársaságok átvették a ponttól-pontig való szállítási rendszert, és a korábbiaktól eltérỏ üzleti stratégiát alkalmazva múködtek (Cento 2009). A liberalizált piac lehetővé tette a fapados társaságoknak, hogy betörjenek az ár-érzékeny piaci szegmensbe (Gillen-Gados 2008; Pels 2008) és a nemzeti légitársaságok által eddig többnyire figyelmen kívül hagyott utazó-közönséget alacsony áraikkal meghódítsák maguknak.

Az európai légi közlekedési piac liberalizációja három programcsomagban valósult meg (Erdósi 1997; 1998; Graham 1998; Doganis 2006; Cento 2009; Dobruszkes 2009b). Az elsố szabályozás 1988. január 1-jén lépett hatályba, mely 
lazított a korábban felállított szigorú szabályokon, csökkentette a kormányok beleszólását a légi közlekedési tarifák megállapításába, engedélyezte az ötödik légi sza-

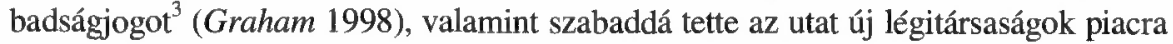
lépése elött. A második csomag (1990. november 1.) tovább lazított a kötöttségeken, lehetővé tette a szabad tarifa- és kapacitáskínálat megállapítását, azonban csak három rugalmas zónán belül, amelyek meghatározott alkalmazási és eladási feltételeknek megfeleltek (Erdősi 1998). Emellett a nyugat-európai légitársaságok előtt lehetőség nyilt arra, hogy megkötések nélkül szállítsanak utasokat és árut az anyaországuk és egy másik európai uniós ország között. A harmadik és egyben leglényegesebb csomag 1993. január 1-jén lépett hatályba, melynek eredményeként teljesen felszabadult az európai uniós piac az EU15 ${ }^{4}$-k légitársaságai előtt (a teljes liberalizálásból átmenetileg kimaradt a kabotázsforgalom ${ }^{5}$ 1997. április 1-ig). A liberalizáció eredményeként lehetővé vált a vállalatok alapításának szabadsága, a légitársaságok teljesen szabad kezet kaptak mind a piaci hozzáférés (beleértve a belföldi piacokat is), mind a kapacitás és arrképzés terén. Nem volt többé akadálya annak, hogy pl. egy ír légitársaság két olasz város között üzemeltessen légi járatokat. A liberalizáció egyik leginkább várt fejleménye a légitársaságok közötti (ár)verseny lett, melynek legnagyobb haszonélvezöivé az utasok váltak, hiszen bővült a kínálat és csökkentek az árak.

Először Észak-Amerikában, azután Európában, mostanában mindenhol a világon a fapados légitársaságok számának drámai növekedése a liberalizáció legfontosabb eredménye. Azonban hiba lenne azt állítani, hogy a fapadosok térhódítása egyesegyedül ennek tudható be. A liberalizált piac szükséges, de nem elegendỏ feltétele a fapadosok nagyméretủ elterjedésének, további fontos katalizátorok meglétére és kölcsönhatására is szükség van - mint pl. egyéni vállalkozók ${ }^{6}$, népességnövekedés és gazdasági jólét, rendelkezésre álló kihasználatlan kapacitással bíró repülőterek, az egyszerüsített eladás és az utazási irodák megkerülése (Francis et al. 2006).

\section{A fapados légitársaságok általános jellemzői}

$\mathrm{Az}$ utóbbi években a fapados légitársaságok megjelenése forradalmasította a légi közlekedést. A fapados üzletmodellt a Southwest vezette be az Egyesült Államokban az 1970-es évek elején, mégis közel 20 évet kellet várni, amíg ez a jelenség világszerte elterjedt (Jászberényi 2003; Franke 2004, Dobruszkes 2006; Malighetti et al. 2009). Az európai fapados légitársaságok bölcsője a Brit-szigeteken volt. Itt jött létre az elsó európai diszkont légitársaság, az ír Ryanair is, amely 1991-ben átalakította addigi üzleti struktúráját és felvette a fapados üzletmodellt (CAA 2006; Groß-Schröder 2007; Cento 2009). 1995-ben megjelent a piacon a Ryanair legnagyobb riválisa, az easyJet is. Mindkét légitársaság gyors és dinamikus növekedést mutatott, és hamar kiterjesztették útvonalhálózatukat Nagy-Britannián kivuuilre is.

Kezdeti sikereiket annak köszönhették, hogy nem a hagyományos légitársaságok utazóközönségét próbálták elcsábítani, hanem figyelmüket egy teljesen új cél- 
csoportra összpontosították, azokra, akik eddig anyagi okok miatt nem tehették meg, hogy repüljenek. A low-cost légitársaságok ezt a hagyományos légitársaságok által elhanyagolt szegmenst az alacsony áraikkal vették rá a repülögéppel történő utazásra (Franke 2004; Gillen-Gados 2008), melynek révén a repülés, az árakat tekintve más közlekedési ágakkal is versenyképessé vált.

Habár a „low-cost légitársaság” fogalmat gyakran úgy használják, mintha egy homogén kategória lenne, vizsgálatok azt igazolják, hogy nincs egy egységes fapados stratégia (Pels 2008), hanem többfajta változata van ennek az üzletmodellnek. Az alap üzletmodellt a Southwest Airlines dolgozta ki, és sikerességét mi sem bizonyítja jobban, minthogy az Egyesült Államok légi közlekedésének történetében egyedüliként a megalakulása óta eltelt 30 évben folyamatosan profitot termel, ráadásul 2001-ben a világ legjövedelmezőbb légitársasága volt (Pate-Beaumont 2006). A fapados légitársaságok által használt üzleti stratégiák között az eltérések abból adódnak, hogy milyen feltételek között alakultak (Francis et al. 2006), valamint az egyes légitársaságok mennyiben vették át a Southwest által úttöröként megalkotott üzletmodellt. Ennek köszönhetően öt üzletmodell jött létre a fapados kategórián belül:

1) Southwest utánzók (Southwest copy-cats)

$\mathrm{Ez}$ a kategória magában foglalja azokat a légitársaságokat, amelyeket független vállalkozók a semmiböl hoztak létre. Ezek a légitársaságok állnak legközelebb az úttörőnek számító Southwest modellhez (pl. Ryanair, easyJet, SkyEurope).

\section{2) Leányvállalatok (Subsidiaries)}

Tipikusan azok a fapados társaságok tartoznak ebbe a kategóriába, amelyek egy nagy múltú hagyományos légitársaság leányvállalatai, és azért alapították öket, hogy részesedést szerezzenek a fapados piaci szegmensből (pl. bmi bmibaby; British Airways - Go; SAS - Snowflake).

\section{3) Árcsökkentök (Cost Cutters)}

E csoport tagjai olyan hagyományos légitársaságok, amelyek az üzemelési költség csökkentésével próbálják imitálni a fapados üzletmodellt. Továbbra is (a hagyományos légitársaságokra jellemző) ún. hub-and-spoke rendszert üzemeltetnek, de racionalizálják repülögépflottájukat (azonos géptípus), valamint megszüntetik az ingyenes fedélzeti ellátást (pl. Aer Lingus).

4) Átalakult charter légitársaságok (Diversified charter carriers)

Ezek olyan low-cost leányvállalatok, amelyeket charter légitársaságok alapítottak, hogy menetrendszerủ fapados szolgáltatásokat is nyújtsanak (pl. TUIfly).

5) Államilag támogatott árversenyzők (State subsidised competing on price)

Az ebbe a kategóriába tartozó légitársaságok nem tekinthetök igazi fapadosnak, mert alacsony áraikat állami támogatás segítségével tudják biztosítani (pl. Emirates). 
Dudás Gábor : A légi közlekedési szektor liberalizációja és az európai fapados piac.

Tér és Társadalom 24. évf. 2010/1. 137-154. p.

TÉT XXIV. évf. 2010 " 1

Kitekintö

143

A Southwest által kifejlesztett üzletforma - alacsony jegyárak, internetes jegyértékesítés, az utasok ponttól-pontig való szállítása, másodlagos vagy kevésbé forgalmas repülöterek használata, rövid (20-30 perces) földöntartózkodás, egyfajta repülőgéptípus (általában Boeing 737), a repülögép fedélzetén egy osztály, szoros „székezettség", több férỏhely stb. - alapján a low-cost légitársaságok képesek 51\%-kal csökkenteni az üzemelési költségeiket a hagyományos légitársaságokkal szemben (Franke 2004; Pels 2008) (2. táblázat). A nyereséget nem elsősorban a repülöjegy eladásból kívánják elérni, hanem egyéb bevételi források igénybevételével (pótdijak, reklámbevételek, autóbérlés, hitelkártyás fizetésből kapott jutalék, utazási biztosítás értékesítése stb.) (Gillen-Lall 2004; Groß-Schröder 2007; Berrittella et al. 2009). Emellett komoly hangsúlyt fektetnek a kiadások csökkentésére, például a hagyományos légitársaságokkal szemben sokkal alacsonyabbak a személyzeti kiadások.

$\mathrm{Az} \mathrm{ECA}^{7}$ kimutatásai szerint (2002) a diszkont légitársaságok alkalmazásában álló pilóták átlag bruttó keresete egy évben 28\%-kal kevesebb, mint a hagyományos légitársaságoknál dolgozó társaiké. Ráadásul a fapados légitársaságok pilótáinak és a személyzetnek $25 \%$-kal hosszabb a munkaideje, kevesebb pihenöidő áll rendelkezésükre, és sokkal több feladatot is kell ellátniuk, pl. repülöút tervezés, csomagberakás, a tankolás ellenőrzése, a repülőgép takarítása stb. (Dobruszkes 2006).

2. TÁBLÁZAT

A fapadosok költségmegtakarításai

(LCC's Sources of Cost Advantage)

\begin{tabular}{|c|c|c|}
\hline & $\begin{array}{c}\text { Árcsökkenés } \\
(\%)\end{array}$ & $\begin{array}{l}\text { Kiadás ülö- } \\
\text { helyenként }\end{array}$ \\
\hline Hagyományos légitársaság & & $100 \%$ \\
\hline \multicolumn{3}{|l|}{ Fapados légitársaság } \\
\hline - szoros székezettség & -16 & 84 \\
\hline - intenzív repülógép használat & -2 & 82 \\
\hline $\begin{array}{l}\text { - alacsonyabb személyzeti és repülési } \\
\text { köitségek }\end{array}$ & -3 & 79 \\
\hline - másodlagos repterek használata & -4 & 75 \\
\hline - egyetlen repülögéptípus & -2 & 73 \\
\hline - minimális földi költségek & -7 & 66 \\
\hline - nem ingyenes a fedélzeti ellátás & -5 & 61 \\
\hline - nincs jutalék az utazási irodáknak & -6 & 55 \\
\hline - alacsony eladási és foglalási költségek & -3 & 52 \\
\hline - kevesebb személyzet és kevesebb iroda & -3 & 49 \\
\hline \multicolumn{2}{|c|}{$\begin{array}{c}\text { A fapados légitársaságok kiadásai a hagyományos } \\
\text { légitársaságokhoz hasonlítva }\end{array}$} & $49 \%$ \\
\hline
\end{tabular}

Forrás: Macário et al. (2007) adatai alapján saját szerkesztés. 
Nem szabad figyelmen kívül hagyni azt sem, hogy nem csak az alacsony árak alkotják, teremtik meg ezt az egyedi üzleti stratégiát. A kereslet irányítása éppen olyan fontos, mint az ellátás és az árak irányítása. Az innovatív árképzési technika (yield management ${ }^{8}$ ) megfelelö használata drága légitársaságoknál is képes profitot teremteni, míg rossz használata a fapadosokat is képes veszteségessé tenni (GillenGados 2008).

\section{A fapados légitársaságok útvonalhálózatának jellemzöi}

\section{A légi közlekedési piac liberalizációja - szabad út a fapadosok elött}

A piaci liberalizáció után, a kezdetekben négy fapados légitársaság szállított utasokat Európában. Közülük is kiemelkedett a Ryanair és az easyJet. Az ezredfordulón a diszkont légitársaságok útvonalhálózata meglehetősen Egyesült Királyság-központú volt, ezen belül is kimagaslott London repülötereinek a szerepe (CAA 2006). Eleinte a low-cost légitársaságokat egyfajta regionális jelenségnek tartották, ami az Egyesült Államok déli részére, valamint az Egyesült Királyság területére szorítkozott (Franke 2004). Ebben a szemléletben drasztikus változás állt be, amikor is a 2001-2003-as években, a légi közlekedési szektorban bekövetkező visszaesés ${ }^{9}$ a hagyományos légitársaságokat érzékenyen érintette, és hatalmas veszteségeket könyveltek el. Ekkor, kihasználva a liberalizált piac nyújtotta lehetôségeket, valamint a nemzeti légitársaságok válságát, Európa-szerte sorra alakultak a diszkont légitársaságok. 2000 után kialakult az Európára ma is jellemző fapados térszerkezet. Ennek két legfontosabb ismertetőjele, hogy megszünt az Egyesült Királyság domináns szerepe, valamint az útvonalhálózatra az észak-dél irányultság lett a jellemző (az Egyesült Királyságból, Németországból és a skandináv térségből a mediterrán térség, Spanyolország, Franciaország déli része és Olaszország felé).

\section{Az Európai Unió keleti bövítésének hatása a fapadosok útvonalhálózatára}

Az Európai Unió 2004-es keleti bővítésének évében a fapados légitársaságok útvonalhálózatára (1-2. ábra) jellemző volt, hogy a városok közötti repülőjáratok elsősorban rövid és középtávon szállították az utasokat, és a nyugat-európai piacra fókuszáltak. A légi útvonalak átlagos hossza $634 \mathrm{~km}$, az átlagos repülési idő 1,4 óra volt. Európában a fapados repülőjáratok $70 \%$-a $1000 \mathrm{~km}$-en belülre szállította az utasokat, és interkontinentális fapados járatok nem közlekedtek (Dobruszkes 2006).

A fapados légitársaságok útvonalhálózata 2004 és 2008 között dinamikusan növekedett (3. táblázat) és az eltelt 4 év alatt megduplázódott az általuk kínált ülés-helyek száma. Ez a növekedés elsősorban a nyugat-európai piacon zajlott, azonban számottevő változás figyelhető meg a nyugat-keleti útvonalakon, amelyek napjainkra $13 \%$-os részesedést szereztek az Európán belüli fapados forgalomból. 
Amennyiben a felkínált üléshelyek száma helyett a low-cost légitársaságok által elérhetö várospárok számát (4. táblázat) vesszuik alapul, még szignifikánsabb különbségek figyelhetők meg. Amíg 2004-ben mindössze 21 várospár között üzemelt fapados járat nyugat- és kelet-európai célállomások között, addig 2008-ban már 285 várospár között közlekedett ilyen légi járat. Ezek az adatok elörevetítenek egy új trendet és az európai fapados piac további bővülésének irányát érzékeltetik.

\begin{tabular}{|c|c|c|c|c|}
\hline \multicolumn{5}{|c|}{$\begin{array}{l}\text { 3. TÁBLÁZAT } \\
\text { A fapados légitársaságok útvonalainak nagyrégiók közötti megoszl } \\
\text { (millió ülésszám) } \\
\text { (Geographical Distribution of the European Low-cost Supply } \\
\text { [Millions of Seats]) }\end{array}$} \\
\hline & \multicolumn{2}{|c|}{ 2004. januar } & \multicolumn{2}{|c|}{ 2008. január } \\
\hline Nyugat - Nyugat & 7,89 & $98 \%$ & 13,4 & $83 \%$ \\
\hline Nyugat - Kelet & 0,14 & $2 \%$ & 2,13 & $13 \%$ \\
\hline Kelet - Kelet & 0,01 & $0 \%$ & 0,07 & $0 \%$ \\
\hline Nyugat - Egyéb & 0,03 & $0 \%$ & 0,57 & $4 \%$ \\
\hline Összesen & 8,08 & $100 \%$ & 16,17 & $100 \%$ \\
\hline
\end{tabular}

Forrás: Dobruszkes (2009a).

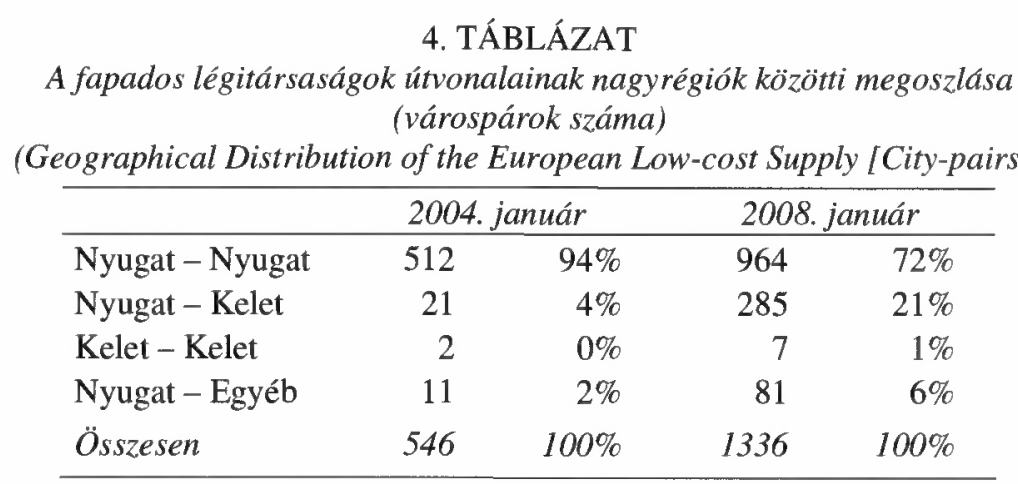

Forrás: Dobruszkes (2009a).

A 2004-es évhez képest a fapados kategóriába sorolható légitársaságok száma csökkent, és a piac egy része kicserélődött, egyes légitársaságok megszủntek (Sterling), egyeseket beolvasztottak (Deutsche BA) és vannak újonnan alakultak is (Wizzair). Az útvonalhálózatukban három jellegzetes elem figyelhetỏ meg: az elérhető célállomások és a várospárok számának növekedése, valamint új kelet-európai célállomások megjelenése $(1-4$. ábra). Ennek következtében a légi közlekedési kapcsolatok sürüsödtek, azonban a korábban kialakult hálózati jellegek döntỏ mértékben nem változtak. Továbbra is jól kirajzolódnak az egyes légitársaságok kapcsolathálózati jellegzetességei, pl. a Flybe elsősorban a Brit-szigetek légi közlekedésére összpontosít, míg a Monarch és a bmibaby a kedvelt spanyolországi célállomásokat részesíti előnyben, és teljes mértékben a turisztikai keresletre összpontosít. 
Dudás Gábor : A légi közlekedési szektor liberalizációja és az európai fapados piac.

Tér és Társadalom 24. évf. 2010/1. 137-154. p.

\section{1. ÁBRA}

Az európai fapados légitársaságok útvonalhálózata, 2004 (a)

(European Low-cost Networks, 2004 [a])
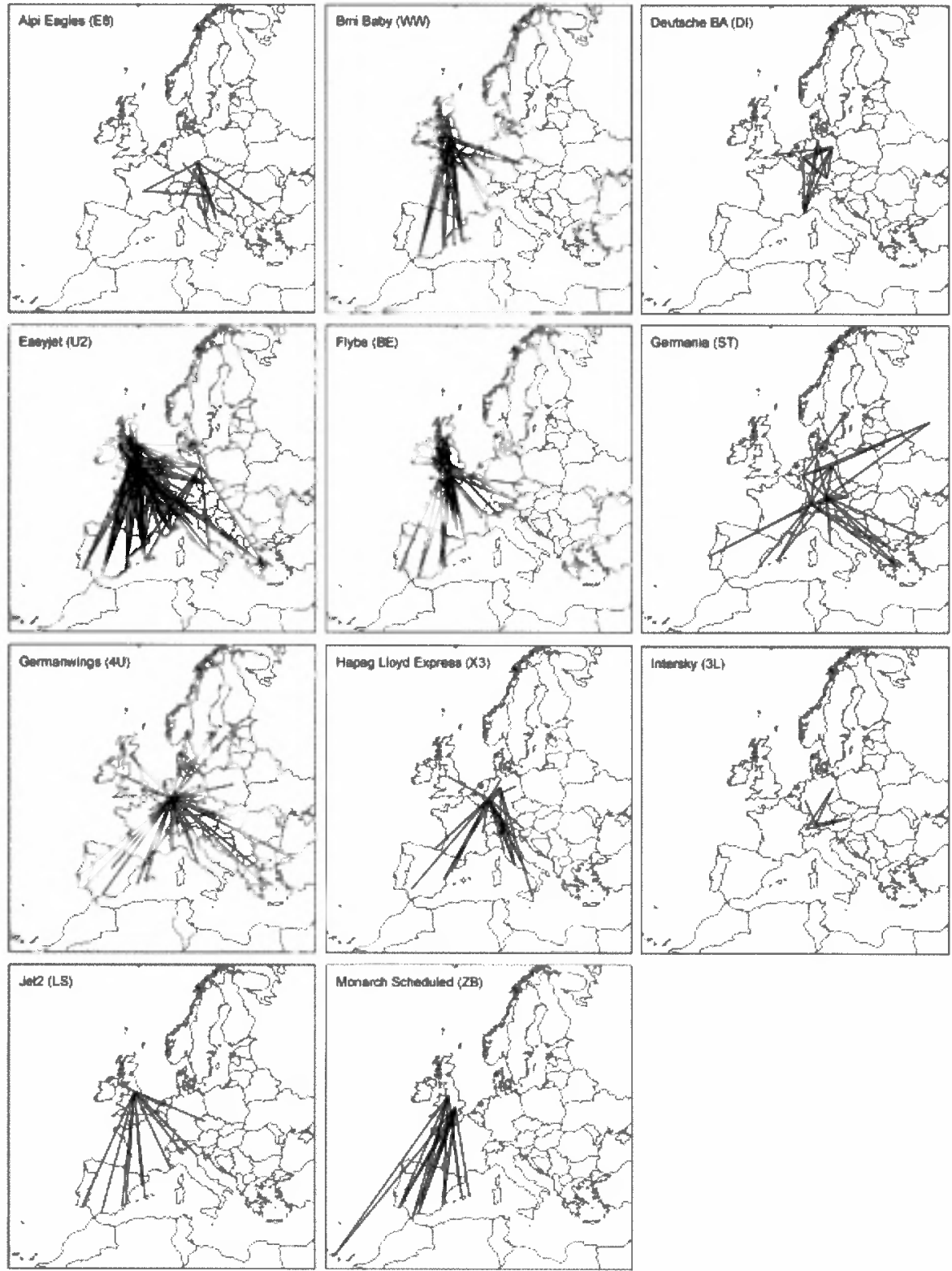

Forrás: Dobruszkes (2006). 
Dudás Gábor : A légi közlekedési szektor liberalizációja és az európai fapados piac.

Tér és Társadalom 24. évf. 2010/1. 137-154. p.

TÉT XXIV. évf. 2010 - 1

Kitekintö

\section{2. ÁBRA}

Az európai fapados légitársaságok útvonalhálózata, 2004 (b)

(European Low-cost Networks, 2004 [b])
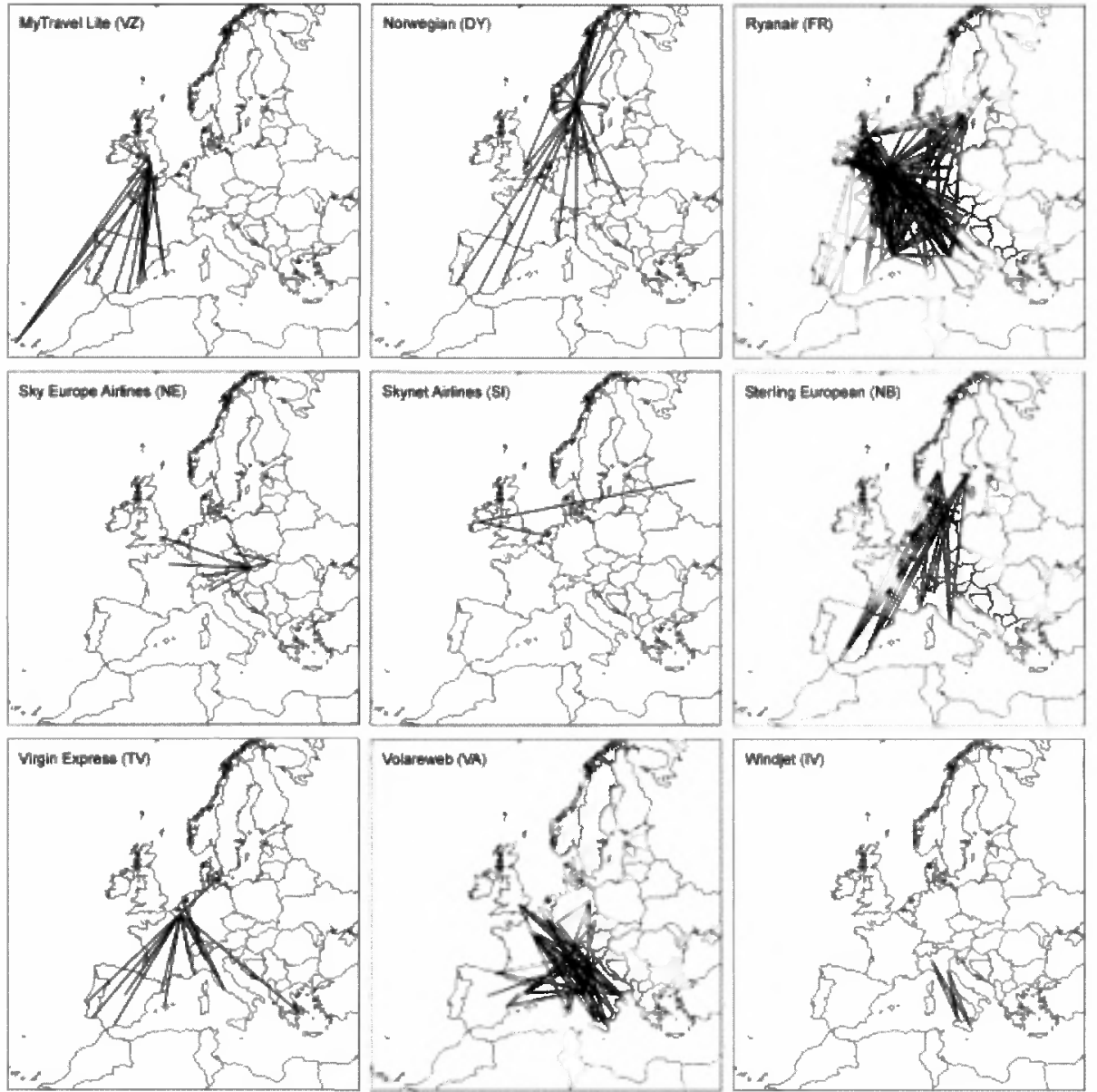

Forrás: Dobruszkes (2006).

A Ryanair és az easyJet folytatja agresszív terjeszkedő politikáját, azonban a stabil nyugat-európai útvonalhálózat mellett a figyelmuik fokozatosan az új kelet-európai piacok felé irányul.

A kelet-európai térségben a nyugati fapados légitársaságok elsősorban a fỏvárosi repülötereket (Budapest, Prága, Bukarest), valamint a nagy népességet tömörítő, illetve vendégmunkásokat kibocsátó, városi térségek repülőtereit (Krakkó, Katowice) vették fel célállomásaik közé.

A három kelet-európai légitársaság közủl a Wizzair rendelkezik a legnagyobb célállomás kínálattal (1. táblázat, 4. ábra), és kizárólag nyugat-keleti várospárok között közlekedtet járatokat. A Wizzair számos útvonalán a nyugat-európai nagyvárosokba szállít utasokat (pl. Budapestről Londonba, Párizsba, Madridba), - mint 
Dudás Gábor : A légi közlekedési szektor liberalizációja és az európai fapados piac.

Tér és Társadalom 24. évf. 2010/1. 137-154. p.

az easyJet -, így a hagyományos légitársaságokkal direkt versenyben van (Dobruszkes 2009a). Útvonalhálózatának másik fontos eleme a lengyel és az angol városok közötti szoros kapcsolat, amit az új üzleti kapcsolatok, valamint a posztmigrációs kereslet indukál.

\section{3. ÁBRA}

Az európai fapados légitársaságok útvonalhálózata, 2009. július (a)

(European Low-cost Networks, July 2009 [a])
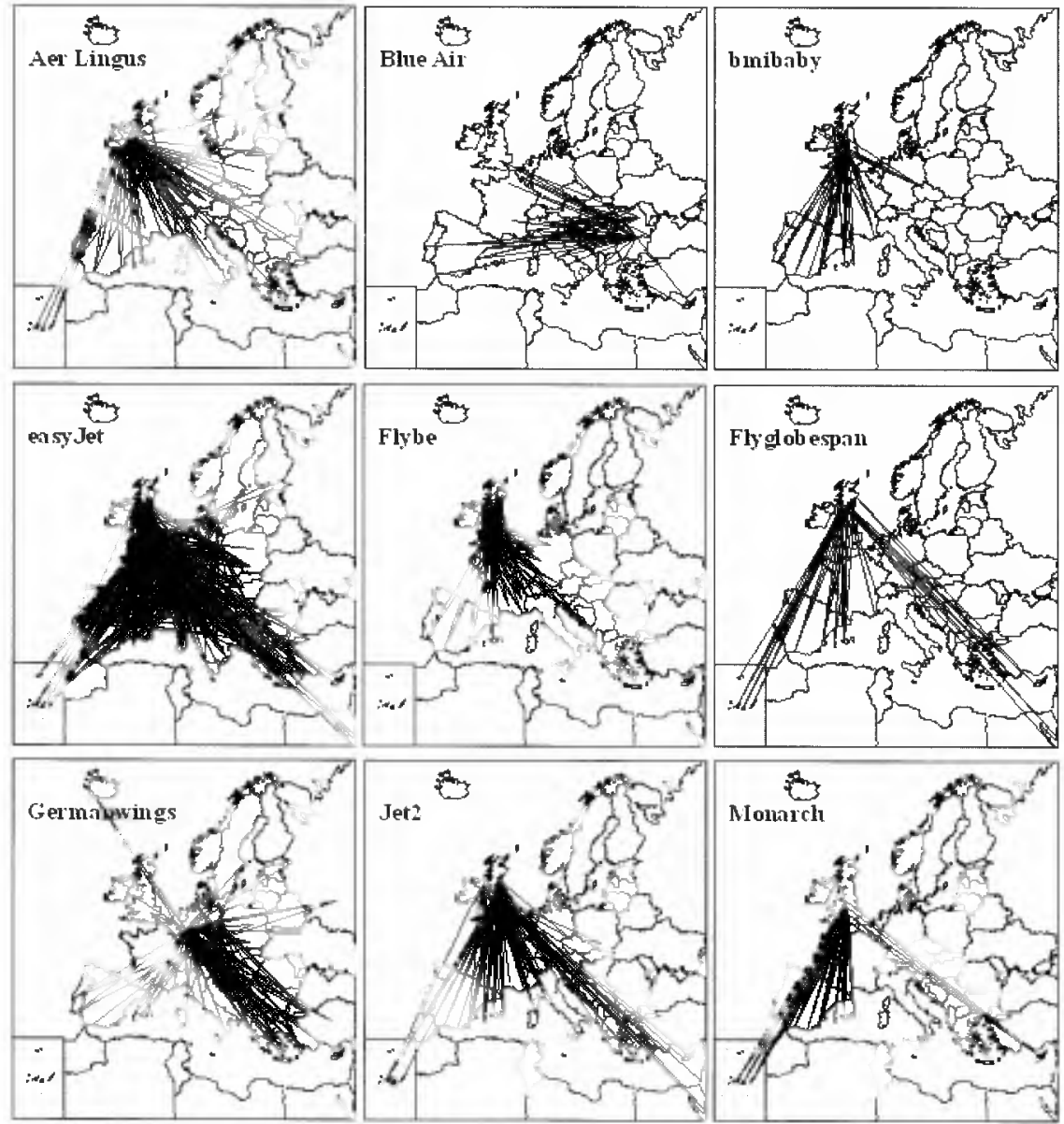

Forrás: A légitársaságok honlapjai alapján saját szerkesztés.

A Blue Air célállomás-kínálatában is szerepelnek a nagy európai fỏvárosok repülöterei, azonban a román diszkont légitársaság elsősorban a szoros román-olasz, valamint román-spanyol kapcsolatokra koncentrál, melynek eredményeként magas az olaszországi célállomások száma, ahova nemcsak a fỏvárosból, hanem a vidéki repülöterekröl (Bacau, Nagyszeben, Kolozsvár) is közlekedtet közvetlen járatokat. 


\section{Dudás Gábor : A légi közlekedési szektor liberalizációja és az európai fapados piac.}

Tér és Társadalom 24. évf. 2010/1. 137-154. p.

A harmadik légitársaság a SkyEurope, amely az első kelet-európai székhellyel alapított diszkont légitársaság volt, és a térség légivállalatai közül elsőként létesített bázist nyugati fỏvárosban (Bécs). Útvonalhálózata hasonlóságot mutat a magyar fapados légitársaságéval, azonban kiterjedése és hálózatának sürüsége sokkal kisebb.

\section{4. ÁBRA}

Az európai fapados légitársaságok útvonalhálózata, 2009. július (b) (European Low-cost Networks, July 2009 [b])
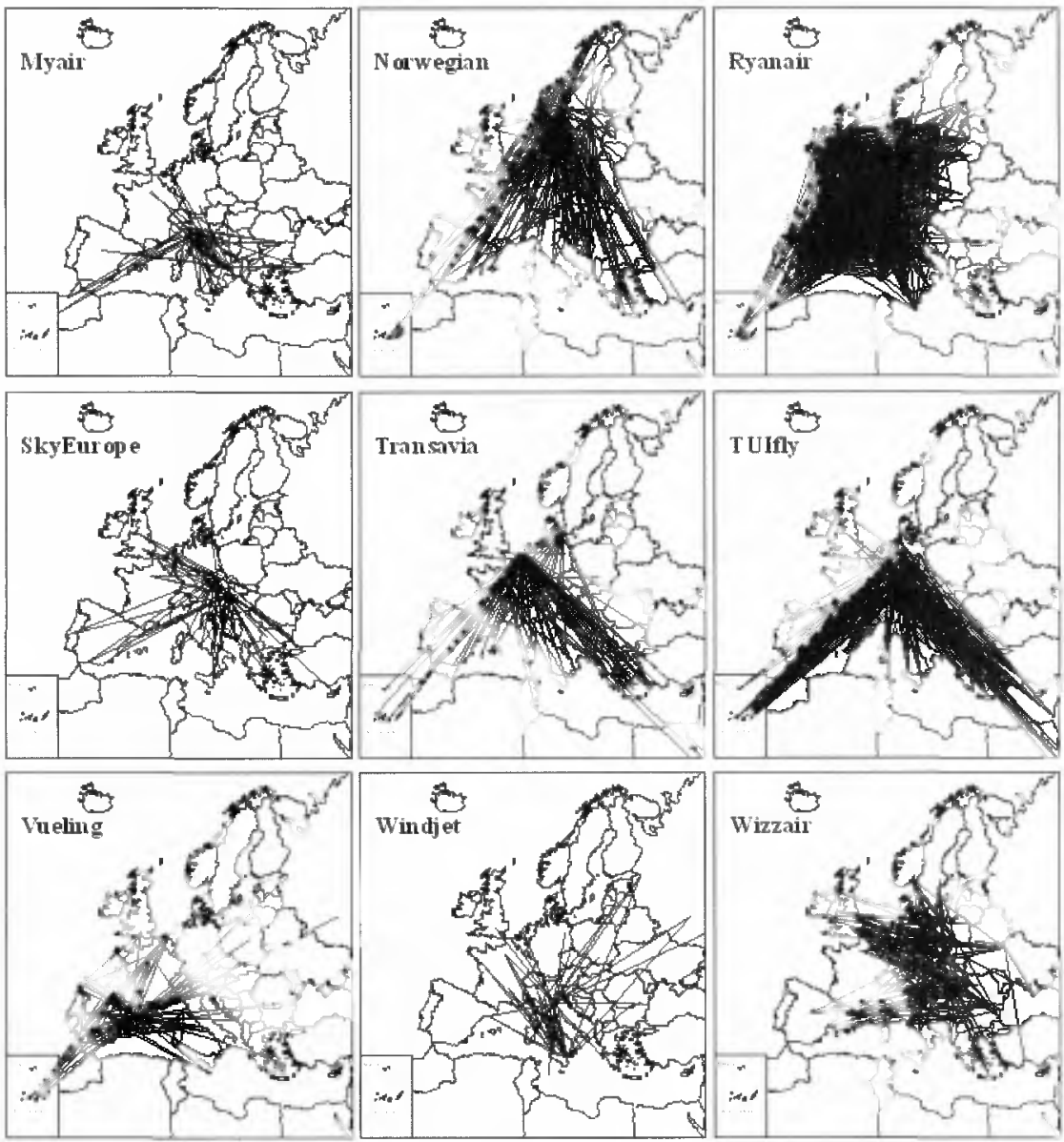

Forrás: A légitársaságok honapjai alapján saját szerkesztés.

\section{Az új nyugat-keleti útvonalak}

A 2004-es európai uniós bỏvítés után a kelet-európai térség is csatlakozott az egységes európai légi közlekedési piachoz, és adottá váltak a feltételek a diszkont légitársaságok további terjedéséhez. A keleti blokk legnagyobb piacterületévé a Visegrádi 
Négyek tömbje vált (Erdösi 2008), ahol a nyugati low-cost légitársaságok mellett megjelentek a kelet-európai székhellyel alapított fapados légitársaságok is (Budapest - Wizzair; Pozsony - SkyEurope; Prága - Smartwings). A kelet-európai kereslet még inkább ár-érzékeny, ezért a fapados légitársaságok az olcsó jegyáraiknak köszönhetően egyre élesebb versenyre kényszerítik a hagyományos légitársaságokat és folyamatosan növelik piaci részesedésüket. Ugyanakkor a nyugati fapados társaságokkal szemben a keletiek lemaradása még mindig jelentős a hálózati sủrüséget és a járatok számát tekintve. Ez annak tudható be, hogy a nyugati társaságok komoly helyzeti előnyt élveznek azzal, hogy egy stabil nyugati útvonalhálózat birtokában kezdték meg müködésüket a keleti piacon, - a nyugat-keleti útvonalak igen kis hányadát teszik ki célállomás-kínálatuknak - ebből kifolyólag nyugodtan kísérletezhetnek új célállomások létesítésével. Ezzel szemben a kelet-európai légitársaságoknak nagyon óvatosan és elöre megfontoltan kell terjeszkedniük (Dobruszkes 2009a). A nyugat-keleti útvonalakat három fö tényezö határozza meg: a nyugati tőke keletre áramlása, a turizmus és a nyugat felé irányuló munkavállalással kapcsolatos migrációs áramlások.

A vasfüggöny megszủnése után a nyugati vállalatok számos termelési egységet felvásároltak, külföldi leányvállalatokat hoztak létre (pl. banki és biztosítási szektor), valamint összeszerelő üzemeket telepítettek a kelet-európai térségbe (Dobruszkes 2009a). Ez megnövelte az üzleti utazások számát, melyek egy részét újabban fapadosok bonyolítják le. A diszkont légitársaságokat elsősorban az egyéni, valamint a kis- és középvállalkozások (1-24; 25-99 fö) részesítik elönyben, míg a hagyományos légitársaságokat jellemzően a több mint 100 embert foglalkoztató nagyvállalatok üzleti utazói veszik igénybe ( $O^{\prime}$ Connell-Williams 2005). Magyarországon a nagyvállalatok többsége még nem használja ki kellő mértékben a diszkont légitársaságok által kínált olcsóbb utazási lehetőségeket, hanem ragaszkodnak a magas színvonalú repülőtéri és fedélzeti szolgáltatásokhoz, a törzsutas programokhoz, valamint a rugalmasabb jegyfoglalási lehetöségekhez ( $K P M G$ 2005).

A turizmust, mint tényezőt vizsgálva megállapítható, hogy a fapados légitársaságot választó nyugati turisták utazási szokásai a nyugat-nyugati útvonalakon elsősorban rövid nyaralások, valamint a második otthon látogatásából állnak (BiegerWittmer 2006). Ezzel szemben a kelet-európai térségbe elsősorban városlátogatási céllal érkeznek. Kelet-Európa nagy múlttal és kulturális értékekkel rendelkezö városai (Prága, Budapest, Krakkó, Riga) az olcsó jegyáraikkal vonzóvá váltak a nyugati turisták számára. Ezt támasztja alá az a felmérés is (Mundruczó 2005), amelyet a fapados légitársaságok járataival Magyarországra érkező turisták körében végeztek. A válaszadók közel fele városlátogatási céllal érkezik hazánkba, és döntő többségük 3-5 éjszakára tervezi az itt tartózkodását. A második helyen a rokonlátogatás, harmadik helyen pedig az üzleti célú utazások szerepeltek.

A migrációs áramlások is egyre növekvő tendenciát mutatnak (Groß-Schröder 2007), hiszen a kelet-európai munkások és egyetemisták egy új kelet-nyugati posztmigrációs áramlást indítottak el, amit a barát- és családlátogatás kategóriába sorolhatunk be (Dobruszkes 2009a). A múltban a migránsok, azok családja, barátaik 
vonattal vagy busszal utaztak, vagy egyáltalán nem utaztak haza. Napjainkban a fapados légitársaságok használata vált a klasszikus módjává az anyaországban élő rokonok és barátok látogatásának, ugyanakkor a kedvezményes jegyárak lehetővé teszik az utazások gyakoribbá válását. A turizmushoz hasonlóan tehát a migráció is új nyugat-keleti áramlásokat ösztönzött. Ez a három összetevő jól kirajzolja a nyugati és keleti országok közötti kapcsolatokat (5. táblázat).

\section{TÁBLÁZAT}

A fö nyugat-keleti fapados piacok

(The Main West-East Low-cost Markets)

\begin{tabular}{lccc}
\hline & $\begin{array}{c}\text { Ülésszám } \\
(\%)\end{array}$ & $\begin{array}{c}\text { Várospárok } \\
\text { száma } \\
\text { 20009. június }\end{array}$ & $\begin{array}{c}\text { Várospárok } \\
(\%)\end{array}$ \\
\hline $\begin{array}{l}\text { Lengyelország <> Egyesültt } \\
\text { Királyság }\end{array}$ & 20,8 & 52 & 11,93 \\
Csehország <> Egyesült & 6,4 & 15 & 3,44 \\
Királyság & 5,3 & 21 & 4,82 \\
Lengyelország <> Németország & 5,2 & 18 & 4,13 \\
Lengyelország <> Írország & 5,0 & 38 & 8,72 \\
Románia <> Olaszország & 5,0 \\
\hline
\end{tabular}

Forrâs: Dobruszkes (2009a), valamint saját számítás.

A legszorosabb kapcsolat Lengyelország és a Brit-szigetek között bontakozott ki. Ennek egyik meghatározó eleme a migrációs áramlások (pl. a lengyelek képezik Írországban a második legnagyobb nemzetiségi csoportot [63 276 fö] a britek után). A gazdasági kapcsolatok sem elhanyagolhatóak, hiszen a három nagy légitársaság (Ryanair, easyJet, Wizzair) kelet-európai célállomásai között szerepel Katowice és Krakkó repülőtere, amely a katowicei speciális gazdasági zóna központja, ahova a Lengyelországba irányuló külföldi tỏkebefektetések túlnyomó része érkezik (Dobruszkes 2009a). A fapadosok útvonalhálózatából kiemelkedik még az olaszromán kapcsolatok erőssége (4. ábra). Ezt nemcsak az Olaszországban éló román nemzetiségủek nagy száma (625 278 fö) és az általuk generált $\mathrm{VFR}^{10}$ turizmus fokozza, hanem a szoros gazdasági kapcsolatok is (elsősorban az olasz kis- és középvállalkozások befektetései a román agrárpiacba, valamint a vendéglátóiparba) (Dobruszkes 2009a).

\section{Összefoglalás}

A légi közlekedési piac liberalizációja új dinamikát adott az iparágnak, és éppúgy, mint szerte a világon, Európában is az új üzleti filozófiát követő piaci szereplők, a fapados légitársaságok megjelenését és megerősödését eredményezte.

A diszkont légitársaságok kihasználták a nemzeti légitársaságok által figyelmen kívül hagyott piaci szegmenst, új keresletet indukáltak, és komoly versenytársaivá váltak a hagyományos légitársaságoknak. A fapadosok számos üzemi és szervezési 
újítást vezettek be a légi közlekedési iparágba (innovatív árképzési technika, közvetlen jegyárusítás Interneten keresztül, ponttól-pontig való szállítás stb.), és újfajta üzletstruktúrájuknak köszönhetően hamar meghatározó piaci részesedésre tettek szert. Habár számos változata létezik a fapados uizletmodellnek, néhány alapazonosító-jelet elkülöníthetünk, mely szerint a repülögép fedélzetén egy osztály van, szoros székezettség jellemzö, nincs fedélzeti ellátás, másodlagos repülöterek használata és nincs csatlakozási lehetöség stb.

A fapadosok útvonalhálózata a korábban elterjedt hub-and-spoke hálózatszervezési modellel szakítva a közvetlen (indulási és célreptér közötti) járatokat favorizálja, és markáns területi sajátosságokat mutat Európában. Az észak-dél irány a meghatározó, tehát az Egyesült Királyság, Németország, Skandinávia térségébỏl a kedvelt turista célállomások felé, mint Spanyolország, Olaszország és Franciaország déli része. A leggyakoribb utazási motiváció a rövid nyaralás, valamint a második otthonok látogatása. Az Európai Unió 2004-es bövítése után a kelet-európai államok is csatlakoztak az európai szabad légi közlekedési piachoz. A liberalizáció nyertesei, a fapados légitársaságok itt is gyorsan megvetették a lábukat.

A vizsgálat kezdetén feltett kérdésre válaszul elmondható, hogy a keleti bővítés óta eltelt idöszakban a fapados társaságok útvonalhálózatainak alapjellemvonásai nem változtak, viszont a hálózatok sủrúbbé váltak és a célállomások száma növekedett. Az újonnan létrehozott nyugat-keleti légi kapcsolatok a nyugati légitársaságok útvonalhálózatában szembeötlő változásokat nem eredményeztek, hiszen a teljes utasforgalom mindössze 13\%-át teszik ki. A keleti piacok keresleti oldalát megvizsgálva arra a megállapításra jutottunk, hogy az utazóközönség három jól elküilöníthető szektorból kerül ki. Ezek az üzleti utazók - az egyéni, valamint kis- és középvállalkozások - új köre, továbbá az elsösorban városlátogatás céljából utazó turisták, valamint a külföldön élő munkások, akik család- és barátlátogatás céljából utaznak vissza hazájukba.

Vizsgálatunk során nem feledkezhettünk meg a gazdasági válságnak a légi közlekedési iparágra gyakorolt hatásáról. A nagy nemzeti légitársaságok hatalmas veszteségeket könyvelnek el, ezért létszámleépítésre, járatritkításokra és útvonalhálózatuk racionalizására kényszerültek. A prognózisok továbbra is borúlátóak. A fapados légitársaságok eredményesebben reagáltak a kedvezötlen folyamatokra, és a megváltozott igényekhez igazodva módosították kínálatukat, azonban néhány diszkont légitársaság így is a válság áldozatául esett, például a Myair vagy a SkyEurope.

A mostani recesszió végeztéig nem tudhatjuk, hogy a keleti piac teljes mértékben kiteljesedett-e vagy további bövülésre lehet számítani. Ha az utóbbi érvényesülne, akkor vajon továbbra is a legjelentösebb nagyvárosi repülőterek között történnének-e vagy épp ellenkezőleg, a bővülés a kelet-európai másodlagos repülötereket célozná meg, mint ahogy az Nyugat-Európában történt?

A nemzetközi elörejelzéseket alapul véve a globális légi közlekedés a következő évben stabilizálódhat, a 2011-es évtöl kezdve ismét emelkedő pályára kerülhet. A fapados légitársaságok jövője azonban a kelet-európai térségben nyitott maradt és további kutatások tárgyául szolgálhat. 
Dudás Gábor : A légi közlekedési szektor liberalizációja és az európai fapados piac.

Tér és Társadalom 24. évf. 2010/1. 137-154. p.

\section{Jegyzetek}

${ }^{1}$ ELFAA - European Low Fares Airline Association - Európai Fapados Légitársaságok Szervezete.

${ }^{2}$ Az árakba beleszámoltuk a reptéri illetéket és a különböző extradíjakat is, mint pl. az üzemanyagpótdíjat.

${ }^{3}$ A legteljesebb, mert arra jogosítja fel az engedélyes ország (saját ország) kijelölt légi fuvarozóját, hogy kétoldalú megállapodásban nem részes harmadik ország (A ország) területén felvett utast, árut vagy postát az engedélyező országba (B ország) szállítson, valamint arra is, hogy az engedélyezö területéról utast, árut vagy postát bármelyik harmadik országba szállítson.

4 1998-ban csatlakozott hozzájuk Norvégia, Izland és Svájc.

5 "A" ország légitársasága üzemeltet belföldi légi járatot „B” országban.

${ }^{6}$ Pl. Herb Kelleher és Rollin King (Southwest); Tony Ryan (Ryanair); Stelios Haji-Ioannou (easyJet); Richard Branson (Virgin Blue).

${ }^{7}$ European Cockpit Association; az 1991-ben alapított szövetség 34 szervezetet foglal magában, amelyek a légi személyzet jogait és érdekképviseletét látják el.

${ }^{8}$ Hozadék menedzsment. Célja a bevétel optimalizálása, maximalizálása, hogy a szolgáltatást a megfeleló szegmensnek a megfelelö időben a megfelelő áron értékesítsük.

${ }^{9}$ A 2001. szeptember 11-i terrortámadások, a 2003-as iraki háború, valamint a SARS-járvány hatására következett be.

${ }^{10}$ Visit Friends and Relatives - Barát- és családlátogatás.

\section{Irodalom}

CAA (2006) No-frills Carriers: Revolution or Evolution? CAP 770. UK Civil Aviation Authority.

Berrittella, M.-Franca, L.L.-Zito, P. (2009) An Analytic hierarchy process for ranking operating costs of low cost and full service airlines. - Journal of Air Transport Management. 5. 249-255. o.

Bieger, T.-Wittmer, A. (2006) Air transport and tourism - Perspectives and challenges for destinations, airlines and governments. - Joumal of Air Transport Management. 1. 40-46. o.

Button, K. (2009) The impact of US-EU „Open Skies” agreement on airline market structures and airline networks. - Joumal of Air Transport Management. 2. 59-71. o.

Cento, A. (2009) The Airline Industry. Physica-Verlag, Heidelberg.

Dobruszkes, F. (2006) An analysis of European low-cost airlines and their networks. - Journal of Transport Geography. 4. 249-264. o.

Dobruszkes, F. (2009a) New Europe, new low-cost air services. - Joumal of Transport Geography. 6. 423-432. o.

Dobruszkes, F. (2009b) Does liberalisation of air transport imply increasing competition? Lessons from the European case. - Transport Policy. 1. 29-39. o.

Doganis, R. (2006) The Airline Business. Routledge, London.

Erdősi F. (1997) A légi közlekedés földrajza. University Press Kiadó, Pécs.

Erdösi F. (1998) A légi közlekedés általános és regionális földrajza, légiközlekedés-politika. I. Kötet. MALÉV, Budapest.

Erdősi F. (2008) Felzárkózás, lépéstartás vagy leszakadás? A légi közlekedés alapvető problémái és területi különbségei Kelet-Európában. II. rész. - Közlekedéstudományi Szemle. 2. 33-43. o.

Francis, G.-Humphreys, I.-Ison, S.-Aicken, M. (2006) Where next for low cot airlines? A spatial and temporal comparative study. - Journal of Transport Geography. 2. 83-94. o.

Franke, M. (2004) Competition between network carriers and low-cost carriers - retreat battle or breakthrough to a new level efficiency? - Journal of Air Transport Management. 1. 15-21. o.

Gillen, D.-Gados, A. (2008) Airlines within airlines: Assessing the vulnerabilities of mixing business models. - Research in Transport Economics. 1.25-35. o.

Gillen, D.-Lall, A. (2004) Competitive advantage of low-cost carriers: some Implications for airports. Journal of Air Transport Management. 1. 41-50. o.

Goetz, A.R.-Graham, B. (2004) Air transport globalization, liberalisation and sustainability: post-2001 policy dynamics in the United States and Europe. - Joumal of Transport Geography. 4. 265-276. o. 
Graham, B. (1998) Liberalization, regional economic development and the geography of demand for air transport in the European Union. - Journal of Transport Geography. 2. 87-104. o.

Graham, B.-Shaw, J. (2008) Low-cost airlines in Europe: Reconciling liberalization and sustainability. Geoforum 39. 3. 1439-1451. 0.

Groß, S.-Schröder, A. (2007) Handbook of Low Cost Airlines - Strategies, Business Processes and Market Environment. Erich Schmidt Verlag GmbH \& Co., Berlin.

Jászberényi M. (2003) A légi közlekedési piac müködése, különös tekintettel a low-cost megjelenésére. I. rész. - Közlekedéstudományi Szemle. 8. 305-308. o.

KPMG (2005) A diszkont légitársaságok szerepe napjaink turizmusában. - Turizmus Bulletin. 2. 48-54. o.

Macário, R.-MacKenzie-Williams, P.-Meersman, H.-Monteiro, F.-Reis, V.-Schmidt, H.-Van de Voorde, E.-Vanelslander, T. (2007) The consequences of the growing European low-cost airline sector. European Parliament, Brussels.

Malighetti, P.-Paleari, S.-Redondi, R. (2009) Pricing strategies of low-cost airlines: The Ryanair case study. - Joumal of Air Transport Management, 4. 195-203. o.

Mundruczó Gy. (2005) A diszkont légi járatokkal Budapestre érkezó külföldi turisták jellemzői. Turizmus Bulletin. 55-61. o.

O'Connell, J.F.-Williams, G. (2005) Passengers' perceptions of low cost airlines and full service carriers: A case study involving Ryanair, Aer Lingus, Air Asia and Malaysia Airlines. - Journal of Air Transport Management. 4. 259-272. o.

Pate, J.M.-Beaumont, P.B. (2006) The European Low Cost Airline Industry: The Interplay of Business Strategy and Human Resources. - European Management Journal. 5. 322-329. o.

Pels, E. (2008) Airline network competition: Full-service airlines, low-cost airlines and long-haul markets. - Research in Transport Economics. 1. 68-74. o.

Selymes, P. (2009) A légi közlekedés gazdasági hatásainak kapcsolatrendszere. - Közlekedéstudományi Szemle. 3. 54-61. o. 